\title{
Casting Membrane of Acrylamide/Polymethacrylic acid and Reinforced by PAC for Application in Fuel Cell Unit
}

\author{
Abdel-Hady EE ${ }^{1}$, El-Toony MM $^{2 *}$ and Abdel-Hamed $\mathrm{MO}^{1}$ \\ ${ }^{1}$ Physics Department, Faculty of Science, Menia University El-Menia City, Egypt \\ ${ }^{2}$ National center for radiation research and technology, Atomic energy authority, Egypt, 3 Ahmad El-Zomr street, P.O. Box 29- Nasr City, Cairo, Egypt. 11370
}

\begin{abstract}
Gamma irradiation poses very important role for casting the polymer membranes. Acrylamide was hydrolyzed by phosphoric acid, while it plays a potential role for coordination of poly methacrylic acid and hydrolyzed acrylamide (acrylic acid) around them. Adding PAC in different ratios for membrane reinforcement besides adsorbing excess of hydrogen proton in aqueous media which enhances proton conductivity. Thermal characterization of the membranes was carried out using thermal gravimetric analysis, while their mechanical properties were investigated by measuring hardness and Chemical description was discussed by studying FTIR and ion exchange capacity (IEC). Morphological characteristics were performed by scan electron microscope. Crystallinity was reviewed using X-ray diffraction which attempts the homogeny of the casted membrane. Electrical resistivity of the membrane was measured resulted in 7 $\mathrm{ohm} / \mathrm{cm}$ while it reduced to $2.7 \mathrm{ohm}$ by temperature rising to $80^{\circ} \mathrm{C}$ which confirmed the availability of the membrane in fuel cell usage.
\end{abstract}

Keywords: Casting; Phosphoric acid; Acrylamide; Methacrylic acid; PAC; Fuel cell; Electrical resistivity.

\section{Introduction}

Wetting of solids by polymer solutions is important in many aspects for polymer processing, including polymer blending, coating of films and production of reinforced polymer composites [1-12]. The influence of the surface on the formation of cast polymer films has mostly been investigated for Langmuir-Blodgett films [1-3], while the influence of wetting phenomena on polymer complex suspensions has been studied intensively in the paint, ink and coating literature [4-6]. The influence of wettability on phase separation of polymer blends [7-10] and co-polymers [11,12] has also been intensively studied. In membrane technology, wetting plays an important role in the preparation of flat-sheet membranes via phase inversion, more in specific during the casting of the membrane dope solution on a solid surface. While industrial production of flat-sheet membranes mostly takes place on woven/non-woven polymeric support layers, a variety of supporting materials is used in lab-scale experiments. Wetting/ dewetting is in this respect often reflected in film shrinkage, either during casting and/or during immersion in the coagulation bath. During the immersion process, stresses are built up in the cast polymer films as a consequence of combined wetting/dewetting phenomena and polymer solidification. This induces the shrinkage of the formed membrane and eventually its release from the support. During the earlier stage of the membrane casting process, shrinkage can also be observed whenever the polymer film has a tendency to dewet the support surface. This is in contrast to the behavior of the same thin film cast on a wettable support, where the thin film remains immobile on the substrate. Numerous studies have been performed on acid-doped membranes concerning its proton conductivity [13-17], thermal stability [18], water drag coefficient [19,20], methanol crossover [21], and fuel cell tests $[15,19]$. The proton conductivity of polymer membranes increased when the acid doping level increased, while the mechanical strength of the membranes decreased significantly at the same time $[19,21]$. Therefore, a doping level of around 5 (5 mol of $\mathrm{H}_{3} \mathrm{PO}_{4}$ per mole of polymer repeat unit) is reported to be the maximum to maintain reasonable mechanical strength of polymer membranes for PEMFC applications. Lifetime tests of polymer based fuel cells showed that mechanical degradation of the membranes under operational conditions is one of the major reasons for the performance degradation of phosphoric acid-doped polymer fuel cells [22,23]. Optimization of casting solvent is very important for membrane fabrication as it affects the consequent separation performance. Macro-phase separation can be observed for blended membranes cast from polymer/solvent solution, and asymmetric membranes are prepared by phase separation methods [24]. Different solvent pairs result in different membrane morphology and performance. For symmetric (dense) membrane also, fabrication conditions can markedly affect permeation properties [25]. The membrane behavior of a given polymer strongly depends on both the intrinsic material properties and the membrane fabrication conditions. Moreover, practical applications, it is essential to understand the consequences of membrane fabrication conditions, e.g. the effect of solvent selection on the physical structure of the membranes must be carried out. Under the program of the New Energy and Industrial Technology Development Organization, Sanyo Electric Corp., Toshiba Fuel Cell Power System Corp., Matsushita Electric Industrial Corp., Ebara Ballard Corp. and Aishin Seiki Corp. have been examining the possibility of commercializing a $1 \mathrm{~kW}$-class PEMFC residential system based on polymer membranes that operates in the temperature region $70-80^{\circ} \mathrm{C}$. Such low-temperature operation is an advantage of this type of fuel cell, but it also causes some problems, including low electrical efficiency $[26,27]$ and CO poisoning of the platinum catalyst $[28,29]$. Furthermore, polymer electrolytes only exhibit high proton conductivities at high humidities. High-temperature PEMFCs (HT-

${ }^{*}$ Corresponding author: El-Toony MM, National center for radiation research and technology, Atomic energy authority, Egypt, Tel/Fax: +202 22944 803; E-mail: Toonyoptrade@yahoo.com

Received September 28, 2011; Accepted January 19, 2012; Published January 26, 2012

Citation: Abdel-Hady EE, El-Toony MM, Abdel-Hamed MO (2012) Casting Membrane of Acrylamide/Polymethacrylic acid and Reinforced by PAC for Application in Fuel Cell Unit. J Membra Sci Technol 2:111. doi:10.4172/21559589.1000111

Copyright: ( 2012 Abdel-Hady EE, et al. This is an open-access article distributed under the terms of the Creative Commons Attribution License, which permits unrestricted use, distribution, and reproduction in any medium, provided the original author and source are credited. 
PEMFCs) have the potential to solve the problems inherent with LTPEMFCs. In order to realize such a HT-PEMFC, a number of basic polymers have been investigated for the preparation of acid-base electrolytes, including polybenzimidazole (PBI) [30], polyethylene oxide (PEO) [31], polyvinyl alcohol (PVA) [32,33], polyacrylamide (PAAM) [34,35], and polyethylenimine (PEI) [36]

In this work casting of hydrolyzed acrylamide with polymethacrylic acid powdered, inserted through PAC. Different gamma irradiation doses were used for membrane compatiblization and composite preparation. Characterization of the membranes using FTIR, thermal gravimetric analysis (TGA), X-ray diffraction (XRD) and Scanning Electron Microscope (SEM). Some parameters were measured such as Ion Exchange Capacity (IEC) and water uptake prior to investigate electrical resistivity which reduced with raising temperature up to $80^{\circ} \mathrm{C}$.

\section{Experimental}

\section{Materials}

- Commercial polymethacylic acid powder and powdered activated carbon (PAC) were purchased from OPTCo, Egypt.

- Reagent grade, Acrylamide of purity $98.5 \%$ was purchased from Cytec co., Italy, while phosphoric acid of purity $99.8 \%$ were supplied by Merck, Germany, other chemicals such as solvents, alkali acids etc., were reagent grade.<smiles>C=C(C)C(=O)O</smiles>

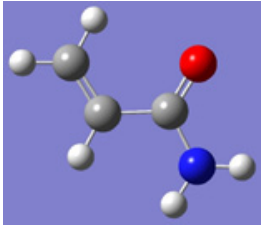

Methacrylic acid- (Picture1) $\quad \mathrm{NH}_{2}-\mathrm{C}(=\mathrm{O})-\mathrm{CHCH}_{2}-$ Acrylamide (Picture 2)
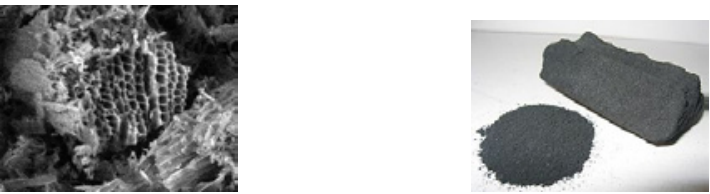

Activated carbon as seen at SEM-(Picture 3)

PAC as seen by naked eye-(Picture 4$)$

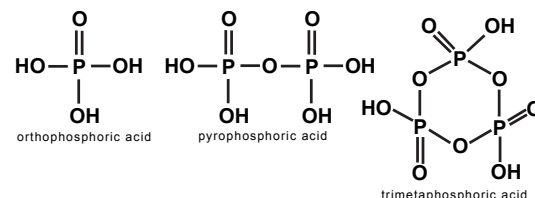<smiles>O=P(O)(O)OP(=O)(O)OP(=O)(O)O</smiles>

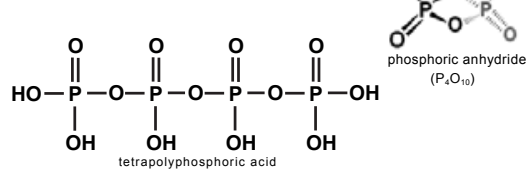

Series of polyphosphoric acids-(Picture 5)

\section{Preparation of grafted membrane}

$10 \%$ of Acrylamide was solvated in double distilled water, with addition $1 \%$ of phosphoric acid, $1 \%$ polymethacrylic acid and powdered activated carbon for different ratios $0.5 \%, 1 \%$ and $2 \%$ to the acrylamide used. The content of the ceiled vial was heated at $80^{\circ} \mathrm{C}$ for 3 hours. Pouring the viscous solution into clean and dry glass petridish in different thickness was performed. The petridish content was exposed to $\gamma$-rays from a ${ }^{60} \mathrm{Co}$ source with different doses. Evaporation of the irradiated soft gelatinous mixture in ambient temperature for 48 hours till attaining casted membrane was done. It detached carefully from the petridish while it kept in dried ceiled vial.<smiles>C=CC(=O)O</smiles>

Acrylic acid-(Picture 6)

Ammonium polyphosphate is an inorganic salt of polyphosphoric acid and ammonia containing both chains and possibly branching. Its chemical formula is $\left[\mathrm{NH}_{4} \mathrm{PO}_{3}\right]_{\mathrm{n}}$ showing that each monomer consists of an orthophosphate radical of a phosphorus atom with three oxygens and one negative charge neutralized by an ammonium anion leaving two bonds free to polymerize. In the branched cases some monomers are missing the ammonium anion and instead link to three other monomers. The properties of ammonium polyphosphate depend on the number of monomers in each molecule and to a degree on how often it branches. Shorter chains are more soluble and less thermally stable, but short polymer chains (e.g. pyro-, tripoly-, and tetrapoly-) show increasing solubility with increasing chain length.<smiles>COP(=O)([O-])OP(=O)([O-])OP(=O)([O-])OP(=O)(OC)OP(=O)(OC)OC(C)(C)P(=O)([O-])OC</smiles>

Different contribution of Ammonium phosphate-(Picture 7)

$\mathrm{NH} 4+-\mathrm{O}-\mathrm{P}(=\mathrm{O})(\mathrm{OH}) 2=\mathrm{NH} 6 \mathrm{PO} 4=\mathrm{NH} 4 \mathrm{H} 2 \mathrm{PO} 4=$ ammonium dihydrogen phosphate $=$

$\mathrm{OH}$

.........-...

$\mathrm{H} 4 \mathrm{~N}$...O-P $=\mathrm{O}$

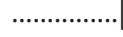

................

$\mathrm{NH} 4+-\mathrm{O}-\mathrm{P}(=\mathrm{O})(-\mathrm{OH})-\mathrm{O}-+(\mathrm{NH} 4)+=\mathrm{N} 2 \mathrm{H} 9 \mathrm{PO} 4=(\mathrm{NH} 4) 2 \mathrm{HPO} 4=$ ammonium hydrogen phosphate $=$

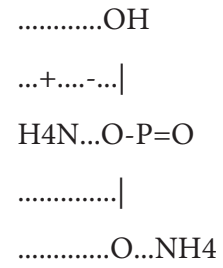




\section{....................+}

Triammonium phosphate (NH4)3PO4 (including 3x water of crystallization)

$$
\begin{aligned}
& \text {...............+ } \\
& \ldots . . . . . . . \mathrm{O} . . . \mathrm{NH} 4 \\
& \ldots+\ldots .+\ldots \mid
\end{aligned}
$$

$\mathrm{H} 4 \mathrm{~N} . . . \mathrm{O}-\mathrm{P}=\mathrm{O} \times 3 \mathrm{H} 2 \mathrm{O}$

(..............

.................NH4

(n......

\section{Theoretical approach}

Acrylamide was hydrolyzed by water in presence of phosphoric acid, to acrylic acid while poly ammonium phosphate was synthesized. Orientation of acrylic acid and poly methacrylic acid around the ammonium phosphate polymer chain facilitate transfer of hydrogen proton through the net matrix. PAC has a potential role for sorbing any migrated hydrogen protons which enhance their conductivity. Beside the previous mentioned role played by PAC that, it has highly electrical properties which facilitates the exchanging of hydrogen protons leading to amplification of hydrogen proton conductivity. These casted membranes have high water swelling properties due to their introduced hydrophilic properties beside their affinity to making permanent hydrogen bond with water.

\section{Water uptake studies}

Respective water uptake/swelling behavior of different ratios of grafted membranes and foam were studied in water as a function of different doses (KGy), and different composition. Swollen polymer was wiped off with tissue paper and then weighed immediately to know the swelling percent or water uptake percent, which was calculated as:

$$
\text { Water uptake } \%=\frac{\begin{array}{l}
\text { Weight of swollen grafted membrane }- \\
\text { Weight of dry grafted membrane }
\end{array}}{\text { Weight of dry grafted membrane }} \times 100
$$

\section{Ion Exchange Capacity (IEC)}

IEC of the polymer membranes was measured using a typical titration method. The dried membrane in the protonic form was immersed into $25.00 \mathrm{~mL}$ of $3 \mathrm{M} \mathrm{NaCl}$ solution for $24 \mathrm{~h}$. A large excess of $\mathrm{Na}^{+}$ions in the solution ensured nearly complete ion exchange. Then, $10.00 \mathrm{~mL}$ of the $3 \mathrm{M} \mathrm{NaCl}$ solution containing the released $\mathrm{H}^{+}$ ions was titrated against $0.05 \mathrm{M} \mathrm{NaOH}$ solution using phenolphthalein as indicator. The IEC was calculated using the following equation:

$$
\mathrm{IEC}_{\exp }=\frac{0.05 \times \mathrm{V} \mathrm{NaOH} \times \mathrm{n}}{\mathrm{Wdry}}(\text { m.equiv. } / \mathrm{g})
$$

Where $V \mathrm{NaOH}(\mathrm{mL})$ is the volume of the $0.05 \mathrm{M} \mathrm{NaOH}$ solution used for titration. $n$ is the factor corresponding to the ratio of the amount of $\mathrm{NaCl}$ solution taken to immerse the polymer $(25.00 \mathrm{~mL})$ to the amount used for titration $(10.00 \mathrm{~mL})$, which is $2.5, W_{\text {dry }}(\mathrm{g})$ is the dry weight of the polymer electrolyte membrane in the protonic form.

\section{Ac Impedance Measurement}

Proton conductivity measurements of casted membranes were carried out. Proton conductivity measurements were derived from AC impedance spectroscopy measurements over a frequency range of 50 to $10^{6} \mathrm{~Hz}$ with an oscillating voltage of $50-500 \mathrm{mV}$, using a system 3532 Hioiki bridge LCR hitester. Each membrane sample was cut into sections $2.5 \mathrm{~cm} \times 2.5 \mathrm{~cm}$ prior to being mounted in the cell. The cell was placed in a temperature controlled container open to air by a pinhole where the sample was equilibrated at $100 \% \mathrm{RH}$ at ambient atmospheric pressure and clamped between two electrodes. The proton conductivities of the samples were measured in the longitudinal direction and were calculated from the impedance data, using the following relationship:

$$
\sigma=\frac{1}{R S}
$$

where $\sigma$ is the proton conductivity (in $\mathrm{S} / \mathrm{cm}$ ), $l$ is the distance between the electrodes used to measure the potential $(l=1 \mathrm{~cm}), S$ is the membrane cross-sectional surface area (membrane width $\times$ membrane thickness) for protons to transport through the membrane (in $\mathrm{cm}^{2}$ ) and $R$ is derived from the low intersection of the high frequency semicircle on a complex impedance plane with the $\operatorname{Re}(\mathrm{Z})$ axis.

\section{Scientific Equipments}

FTIR characterization: The functional groups of the grafted membrane were studied using Mattson 1000, Pye-Unicam, England.

Scanning Electron Microscope: Investigation and magnification of the polymer surface was carried out by SEM, JEOL-JSM-5400; Japan.

Thermal Gravimetric Analysis: Shimadzu TGA -50, Japan was used to characterize the thermal stability of the casted membrane.

$\mathrm{X}$-ray diffraction: $\mathrm{X}$-ray diffraction pattern was recorded in the range of diffraction angle $\theta$ on philipe pw 1730, $\mathrm{x}$-ray generated equipped with scintillation counter. The diffraction pattern were run with nickel filter (Cuka), $\lambda=1.54 \mathrm{~A}^{\circ}$. The $\mathrm{X}$-ray diffractogram was obtained using the following experimental condition filament current $28 \mathrm{~mA}$, voltage $40 \mathrm{Kv}$, scanning speed $20 \mathrm{~mm} / \mathrm{min}$.

\section{Results and Discussion}

\section{Characterization of castesd membrane}

FTIR: Poly phosphoric acid ammonium salt shows strong bands at $1040-910 \mathrm{~cm}^{-1}$ theoretically while it appeared at $1074.5 \mathrm{~cm}^{-1}$ that belong to asymmetric stretching vibrations of the $\mathrm{P}-\mathrm{OH}$ group and at $1242 \mathrm{~cm}^{-1}$ that corresponds to $\mathrm{P}-\mathrm{O}$ stretching. At higher poly phosphoric acid ammonium salt ratio, the $\mathrm{P}-\mathrm{O}-\mathrm{H}$ vibration at 937 $\mathrm{cm}^{-1}$ becomes stronger, indicating the existence of excess acidic protons. Additionally, phosphoric acid units give rise to broad bands with medium intensity at $1714 \mathrm{~cm}^{-1}$ and $2903-2842 \mathrm{~cm}^{-1}$ as seen in (Figure 1a, 1b, 1c and 1d). The intensity of these peaks increased in parallel with the concentration of phosphoric acid grafted through the net matrix while as PAC increased its concentration the peak intensity tend to be less. The band broadening around $3174 \mathrm{~cm}^{-1}$ is due to the hydrogen bonding network which is necessary for proton conduction.

Thermal gravimetric analysis: The increase powdered activated carbon into the casted membrane improved their thermal stability. The thermogram could be divided into 5 divisions. First division described the membrane stability upon raising the temperature (working temperature of the membrane). This division has a temperature range up to $100^{\circ} \mathrm{C}$, at which no loss of weight has been seen. Second division explained the slow weight decrease upon raising the temperature. The loss of weight through which was $6 \%$ for $1 \%$ PAC while it increased to 
Citation: Abdel-Hady EE, El-Toony MM, Abdel-Hamed MO (2012) Casting Membrane of Acrylamide/Polymethacrylic acid and Reinforced by PAC for Application in Fuel Cell Unit. J Membra Sci Technol 2:111. doi:10.4172/2155-9589.1000111

$8 \%$ by raise the PAC content to $3 \%$ which may be due to promotion of volatile gasses by PAC insertion into the casted membrane. The range of temperature through this division was $100-220^{\circ} \mathrm{C}$ for $3 \% \mathrm{PAC}$ and from $100-200^{\circ} \mathrm{C}$ for $1 \%$ PAC casted membrane. The third division described the convex zone regarding to temperature axe. The weight loss through $\mathrm{PAC} /$ casted membrane was $17 \%$ for $3 \% \mathrm{PAC}$ and $15 \%$ for $1 \%$ to a range of $220-330^{\circ} \mathrm{C}$ while it reduced for $3 \% \mathrm{PAC}$ of the membrane to a range of $220-230^{\circ} \mathrm{C}$. The fourth division described the abrupt change of weight by temperature raising up, via which $1 \%$ PAC membrane, the temperature range was $320-370^{\circ} \mathrm{C}$ while it expanded to a range of 320 $380^{\circ} \mathrm{C}$ for $3 \%$ PAC-membrane. The weight loss through this division showed similar loss of weight for 1 and 3\% PAC /membrane which was $13 \%$. The fourth division showed a weight reduction to $52 \%$ from the original weight for $1 \%$ PAC-membrane while it was $50 \%$ for $3 \%$ PACmembrane. This loss of weight has performed up to $550^{\circ} \mathrm{C}$.

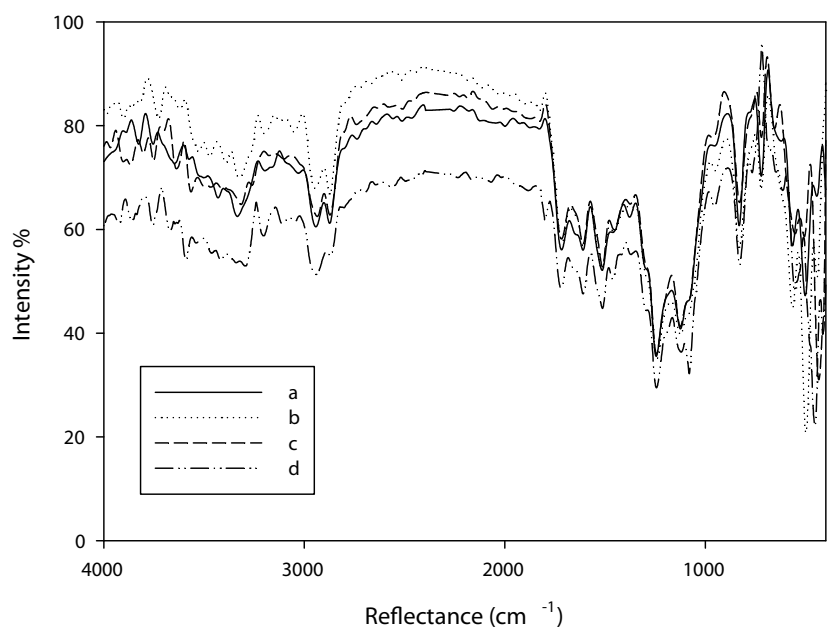

Figure 1: FTIR of polymethacrylic acid and poly phosphoric acid ammonium salt blend at different Gamma irradiation dose (KGy).

a) $10 \mathrm{KGy}$ irradiation dose and $0.1 \% \mathrm{PAC}$

b) 20 KGy irradiation dose and $0.1 \%$ PAC

c) $20 \mathrm{KGy}$ irradiation dose and $0.2 \%$ PAC

d) 20 KGy irradiation dose and $0.3 \%$ PAC

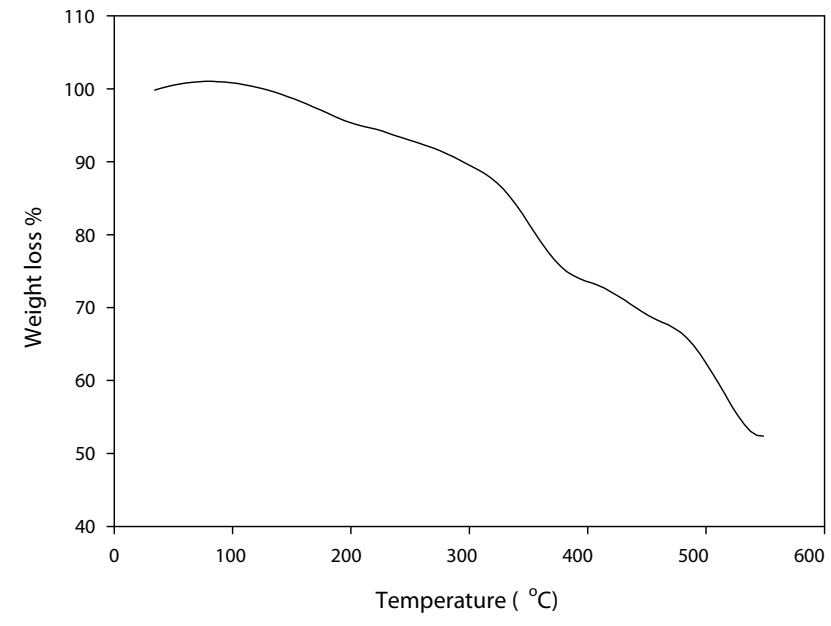

Figure 2: Thermogram of casted membrane of polymethacrylic acid/ polyacrylamide inserted in 1\% PAC at $20 \mathrm{KGy}$ irradiation dose.

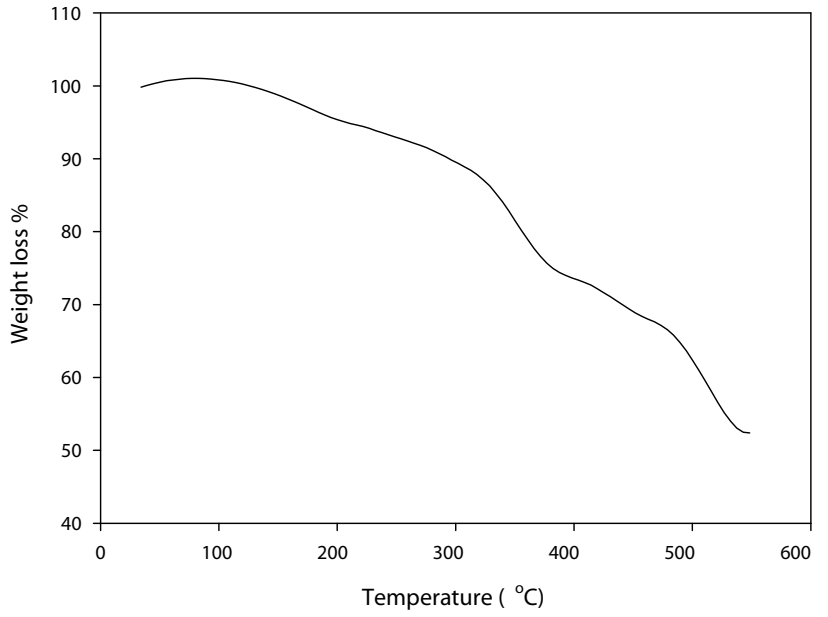

Figure 3: Thermogram of casted membrane of polymethacrylic acid polyacrylamide inserted in 3\% PAC at $20 \mathrm{KGy}$ irradiation dose.

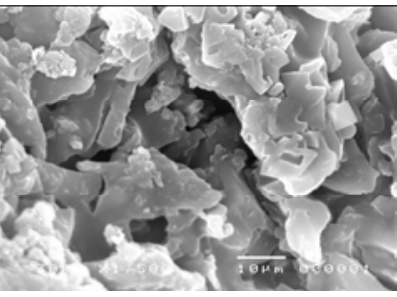

a

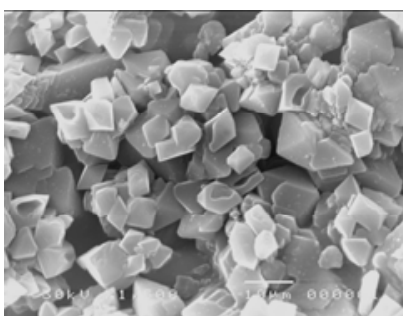

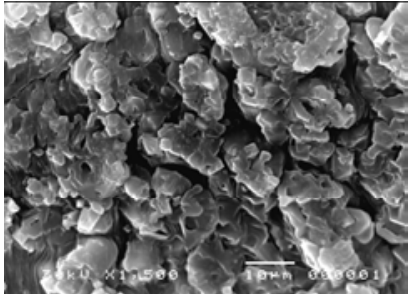

b

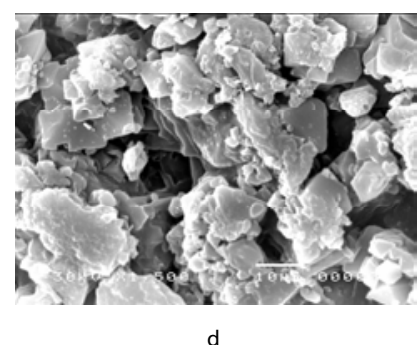

d
Figure 4: Scan electron microscope of polymethacrylic acid and poly phosphoric acid ammonium salt blend at different Gamma irradiation dose (KGy).

a) $10 \mathrm{KGy}$ irradiation dose and $0.1 \%$ PAC

b) $20 \mathrm{KGy}$ irradiation dose and $0.1 \%$ PAC

c) $20 \mathrm{KGy}$ irradiation dose and $0.2 \%$ PAC

d) 20 KGy irradiation dose and $0.3 \%$ PAC

Scanning electron microscope: Figure 4a showed irregular scattering of black aggregates while their distribution is over the net matrix which may explain by more or less reaction of PAC with polymer. It can be seen dark zones distributed over white one which could pointed to less cross-linking of poly methacrylic acid and poly phosphoric acid ammonium salt.

Irradiation plays a very important role for homogenizing polymers comprises the sample. All the particles are appeared to be tightly closed, regular distribution of carbon aggregates in (Figure $4 \mathrm{~b}$ ) which is explained by their diffusion onto deepest layer of matrix. Whitish zones have seen and disappearance of black and white may due to 
cross-linking between poly phosphoric acid ammonium salt and poly methacrylic acid.

By increasing the PAC content as seen in (Figure 4c) it can seen larger content of PAC aggregate diffused into the net polymer while exceeding scattered regularly over the membrane surface. No contact among the PAC aggregates which seen as isolated islands over the sample. Large porous has noticed which may allow larger passage of hydrogen protons and increase the chance of water uptake.

In Figure $4 \mathrm{~d}$ the cross-linking between the two blended polymers have been obviously seen while increase the PAC aggregates forming larger islands and in some cases resemble continuous series of big islands.

$\mathrm{X}$-ray diffraction: The cast membrane showed highest crystallininty at $10 \mathrm{KGy}$ gamma irradiation dose and 2\% PAC content. While the membrane crystallinity decrease with increasing the irradiation dose to $20 \mathrm{KGy}$ as it seen in (Figure 5b). By increasing the carbon content to $2 \%$ the maximum amorphousity has been aroused as it illustrated in (Figure 5c). The hump existed through which confirmed disappearance of the cast crystallinity. The amorphicity start to decrease by increasing the PAC content to $3 \%$ as it shown in (Figure $5 \mathrm{~d}$ ).

\section{Water uptake}

Water uptake is an important property for PEMs which needs to be seriously considered, because the loss of water is anticipated to bring two negative impacts on cell performance: decreased proton conductivity and degraded membrane-catalyst interface [37-39]. To verify the improved hygroscopic property of membranes by incorporating PAC particles, the water uptakes were measured. According to the Eikerling's theory, there are two kinds of water in PEMs [40,41]: one is bound water which solvates the function groups; the other is bulk water which fills the micro-pores. .An increase in the water uptake of membranes with the increase in the irradiation dose (KGy) was observed in (Figure 6). The date of non cross-linked membranes has been also studied. The increase in swelling corresponds well with the higher content of crosslinked phosphoric acid ammonium salt groups, which in turn increase the hydrophilicity in the membrane. The most interesting aspects is that; carbon content increase the water uptake till certain extent over which less water uptake which may due to reactivity of carbon content towards hydrogen proton which disrupted their ease of motion.

\section{Ion exchange capacity}

The ion exchange capacities were determined by acid-base titration and are plotted in (Figure 7). It was found that the ion exchange capacity increases with an increase in the degree of carbon content to certain percent over which it start to decreased. Carbon content played important role in reinforcement of casted membrane, more phosphoric acid groups are incorporated within the membranes, which led the membranes become more hydrophilic and enable to absorb more water in order to enhance the facilitation of the proton $\left(\mathrm{H}^{+}\right)$mobility through the membranes. Figure 7 listed the IEC values of the studied membranes showed the highest IEC value of $0.93 \mathrm{mmolg}^{-1}$ compared with the recast Nafion ${ }^{\circledR}$ of $1.5 \mathrm{mmolg}^{-1}$.The increased IEC value illustrated that a little more acid sites resulting. From acidic poly phosphoric acid ammonium salt resulted and hydrolyzed acrylamide (acrylic acid) particles existed in the membrane composite. The enhanced acid property was expected to promote the membrane proton conductivity at various conditions [42-44].

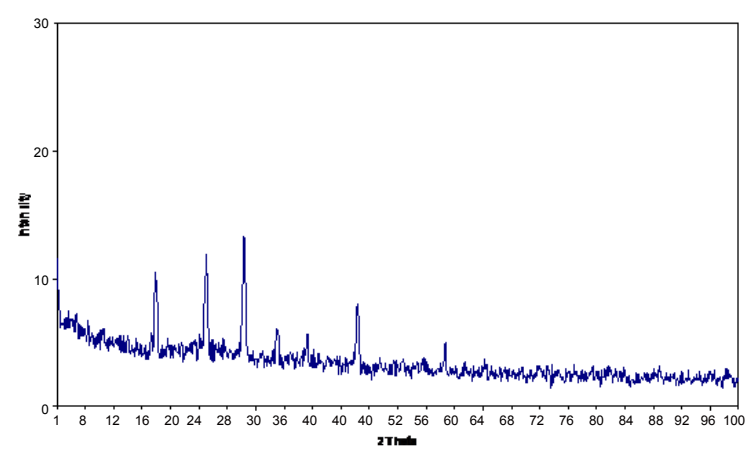

a

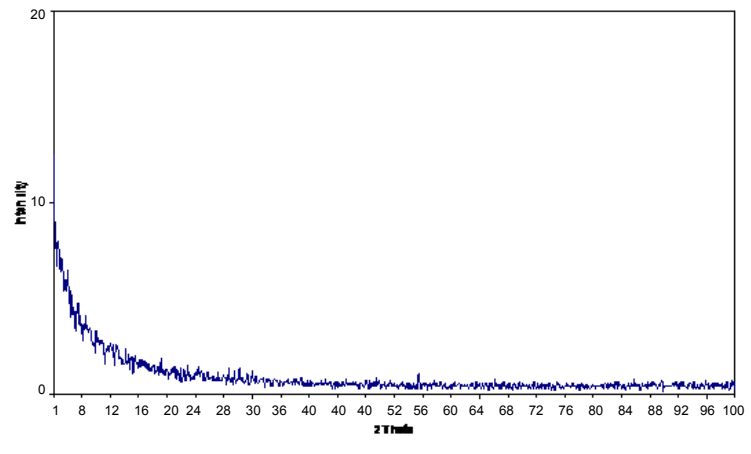

b
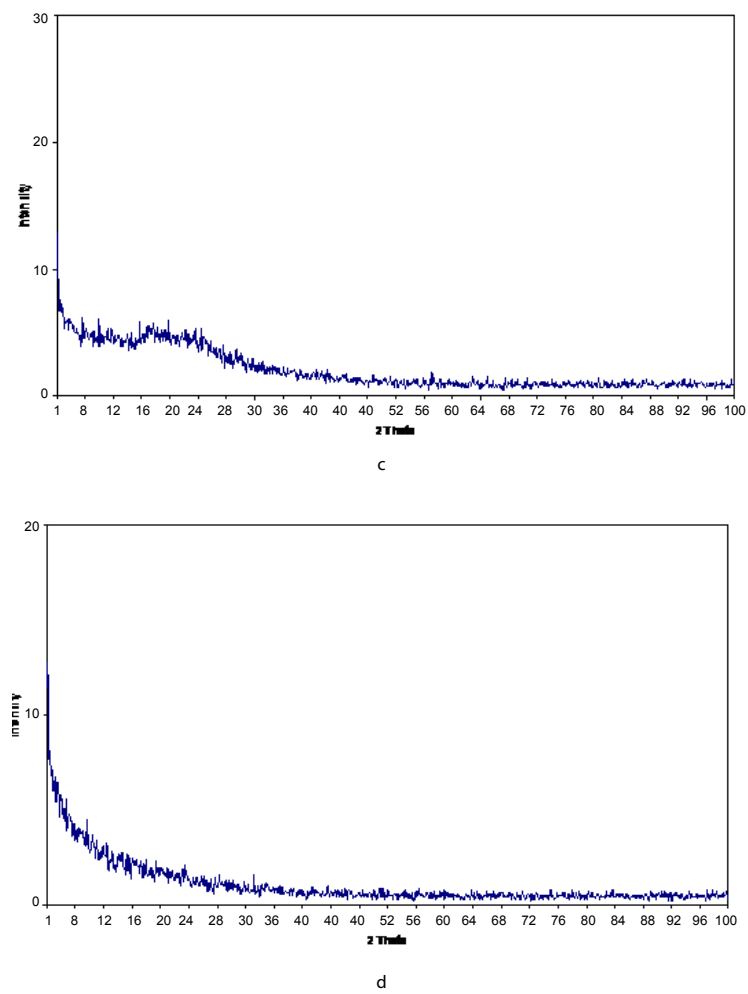

Figure 5: X-ray diffraction of polymethacrylic acid and poly phosphoric acid ammonium salt blend at different Gamma irradiation dose (KGy).

a) $10 \mathrm{KGy}$ irradiation dose and $0.1 \%$ PAC

b) $20 \mathrm{KGy}$ irradiation dose and $0.1 \% \mathrm{PAC}$

c) $20 \mathrm{KGy}$ irradiation dose and $0.2 \%$ PAC

d) $20 \mathrm{KGy}$ irradiation dose and $0.3 \%$ PAC 


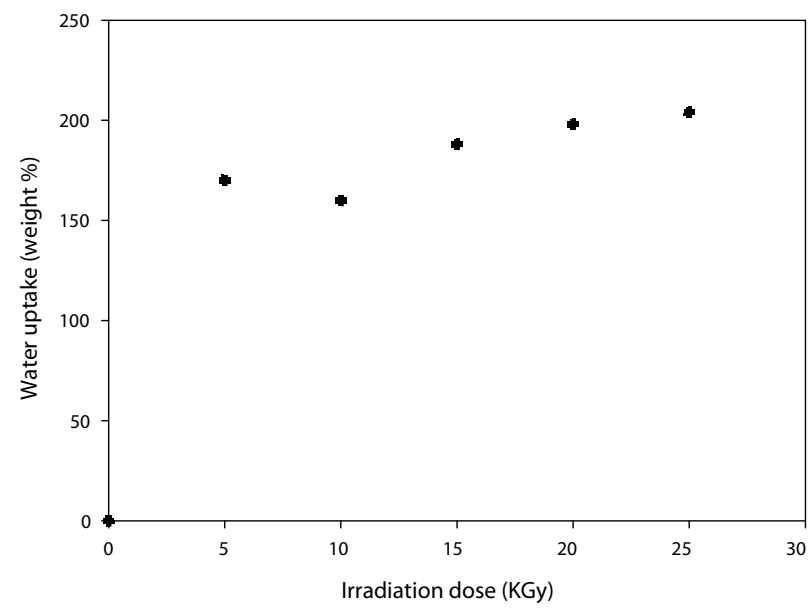

Figure 6: Figure 6: Effect of irradiation dose (KGy) on water uptake of casted membrane (acrylamide/polymethacrylic cast reinforced by PAC)

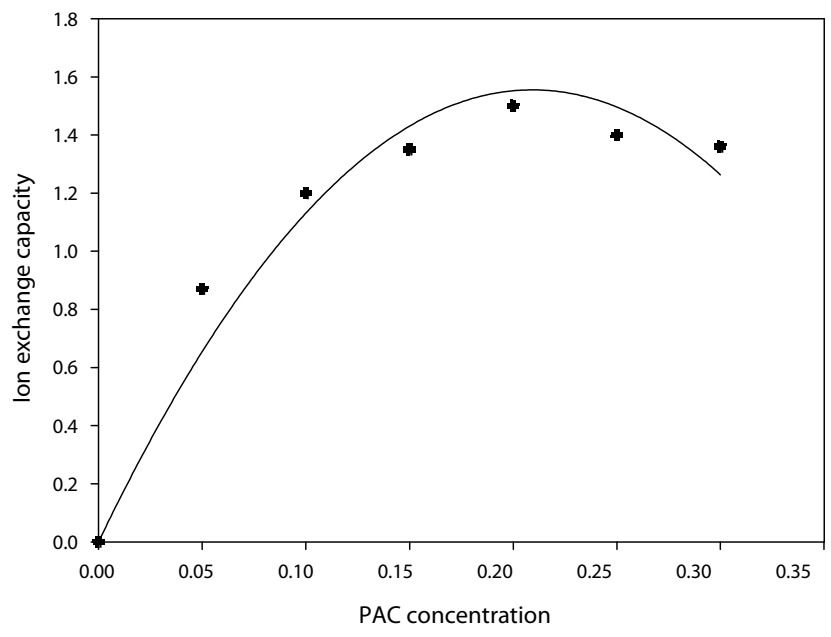

Figure 7: Effect of PAC concentration of casted membrane on ion Exchange capacity (polymethacrylic acid and hydrolyzed acrylamide composite).

\section{Ac impedance}

The proton conductivity of casted membrane (polymethacrylic acid and poly phosphoric acid ammonium salt blend) with various carbon content measured at room temperature is illustrated in (Figure 9). The specific resistivity is decreased with decreasing carbon content. The resistivity decreases from 17 to $7 \mathrm{ohm} \mathrm{cm}^{-1}$ as the carbon percent decreased from 0.3 to $0.05 \%$. This is due to the ionic conductivity is a function of IEC, solvent uptake and hydration number of the membranes was found to be strongly dependence upon the less carbon content which play important role in reinforcement of casted membrane, more phosphoric acid groups are incorporated within the membranes, which conduct the membranes become more hydrophilic and enable to absorb more water in order to enhance proton $\left(\mathrm{H}^{+}\right)$ mobility through the membranes.

Raising the temperature leads to increasing up the kinetic energy of hydrogen proton to be diffused easily through the membrane's active sites. Temperature expands the pore size of the synthesized membrane and so enhancing the proton passage through which. Temperature has
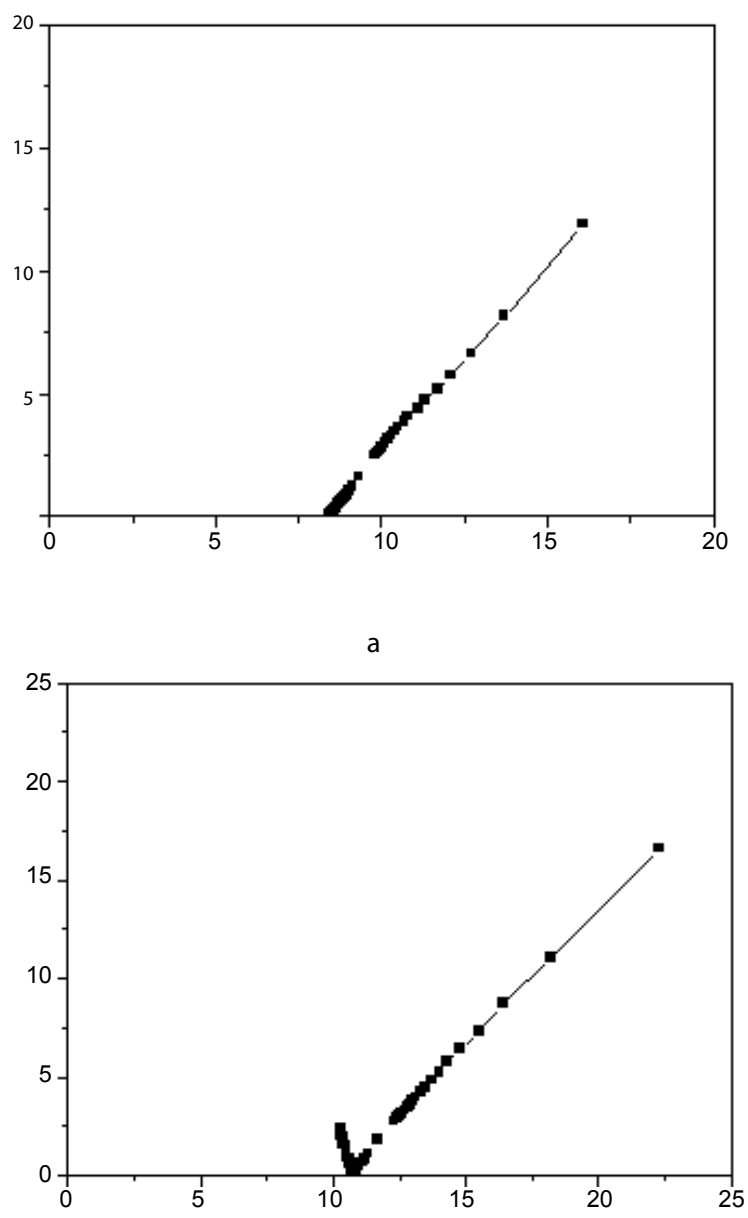

b

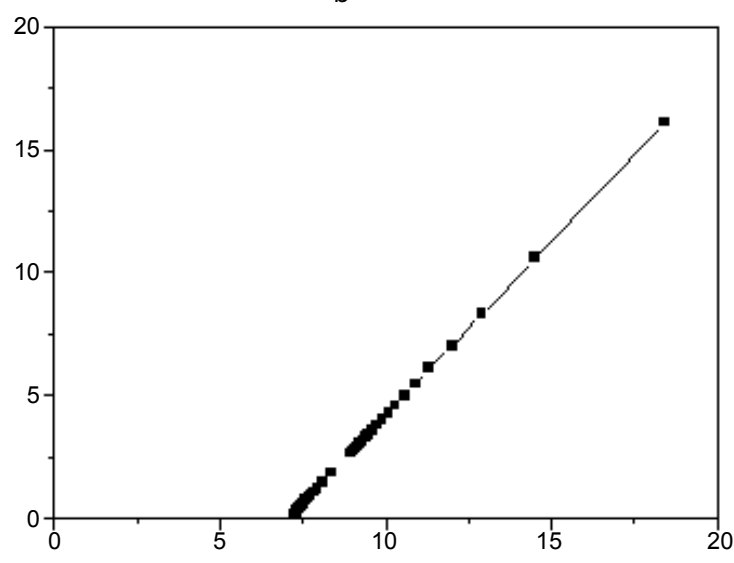

Figure 8: Nyquist plots of the electrodes of the casted membrane (polymethacrylic acid and hydrolyzed acrylamide composite) at different Frequencies

a) $10 \mathrm{KGy}$ irradiation dose and $0.1 \% \mathrm{PAC}$

b) $20 \mathrm{KGy}$ irradiation dose and $0.1 \% \mathrm{PAC}$

c) $20 \mathrm{KGy}$ irradiation dose and $0.2 \% \mathrm{PAC}$ 
a potential role in activate the poly phosphoric ammonium salt and hydrolyzed acrylamide hanged through the membrane net matrix which increase their chance for accept and donate the hydrogen proton. All these factors increasing the electrical conductivity of the membrane as it could be seen in the (Figure 10) decreasing the EC with the temperature is linear relationship in the range of 25 to $80^{\circ} \mathrm{C}$ for the casted membrane [45].

In order to better understand some of the key factors involved in design of a composite membrane, some quantitative models of the conductivity are obtained. One of these models is based on the dusty-fluid model $[46,47]$. It is claimed that the proton diffusion obstruction presented in the polymer matrix is viewed as an additional frictional interaction with large immobile dust or gel particles. Within this framework, the inorganic additive is simply considered as an additional dust species immobilized within the polymer matrix. If the incorporated components are nonconductive (unlike carbon particles), the proton diffusive resistance will be increased and vice versa. So the objective of increased PEM conductivity can be achieved by the

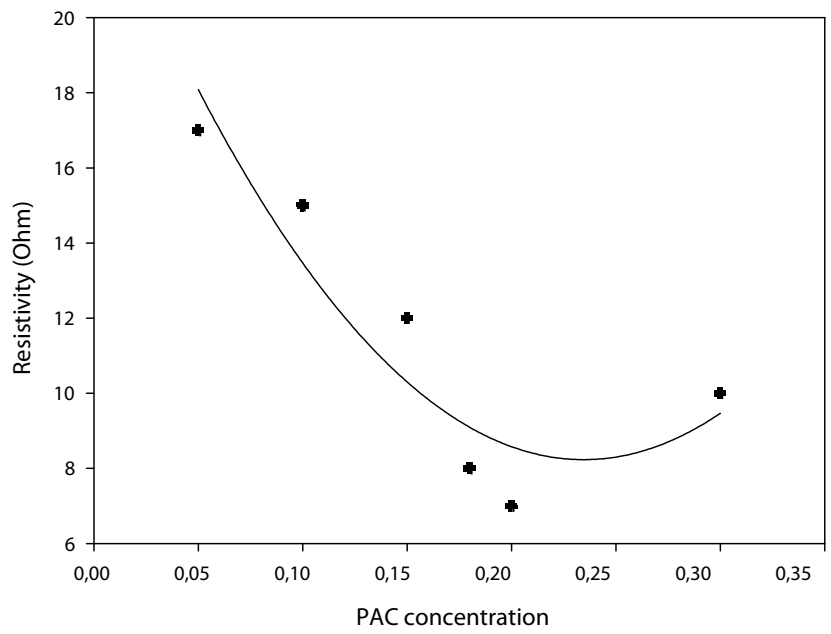

Figure 9: Effect of PAC \% on Resistivity of the casted membrane (polymethacrylic acid and hydrolyzed acrylamide composite)

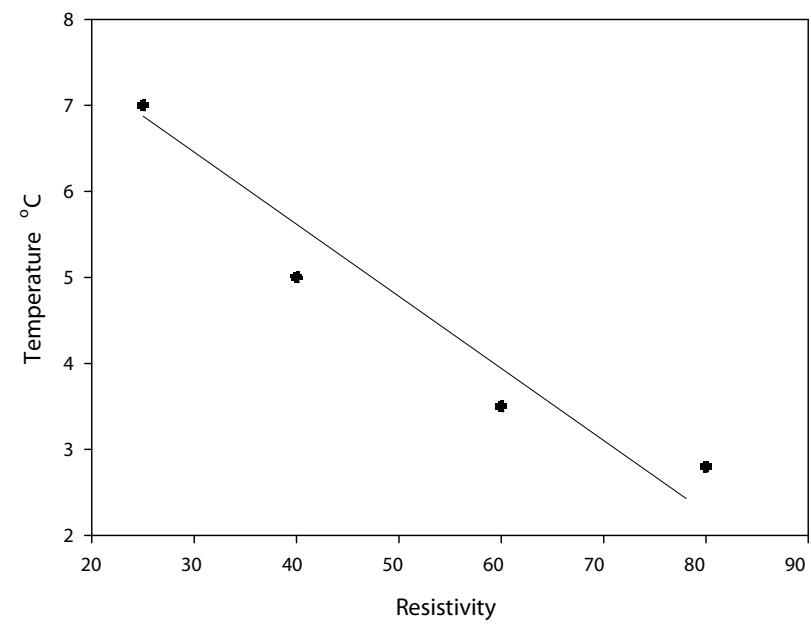

Figure 10: Effect of temperature on the resistivity of the casted membrane (polymethacrylic acid and hydrolyzed acrylamide composite).

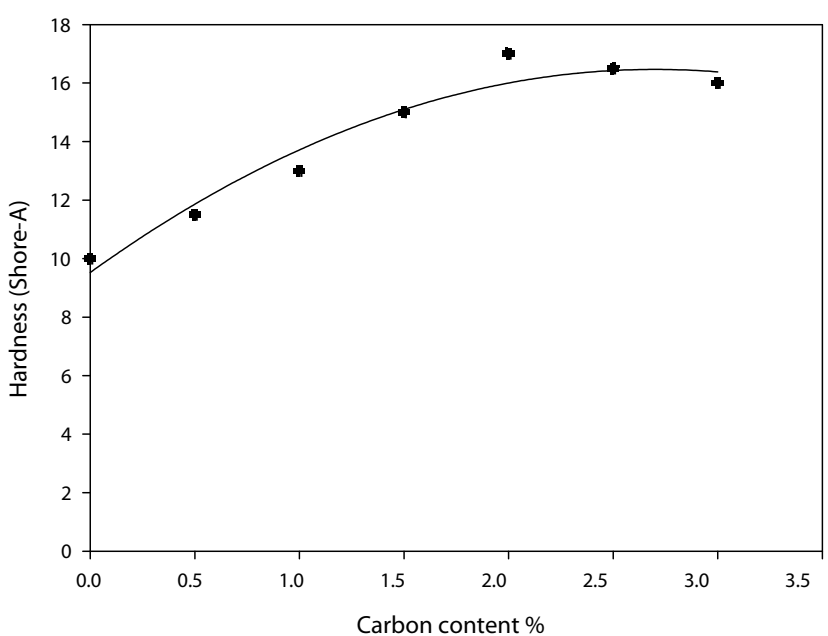

Figure 11: Effect of carbon content on the hardness of the casted membrane (polymethacrylic acid and hydrolyzed acrylamide composite).

presence of acidic additives (like carbon particles) [46]. The presence of acid sites on the surface of carbon particles increases the total numbers of acid sites within the PEM, which correspondingly increases the available numbers of charge carriers and offers more effective proton transfer channels to enhance the proton conductivity.

\section{Hardness testing and durability}

Evaluation of the mechanical properties of casted membrane with variation of carbon content which inserted through them for the purpose of reinforcement. Hardness measurements showed increase their value by increasing the carbon content to $2 \%$ while it decrease with small extent over which till $3 \%$. These results attempt the availability of the membrane and their durability through all the carbon content range.

\section{Conclusion}

This work aims to synthesis low cost and efficient polymer membranes used in fuel cell. Acrylamide was hydrolyzed with phosphoric acid and mixed with polymethacrylic acid to prepare the cast composite. Powdered activated carbon (PAC) was inserted into the cast mixture for membrane reinforcement and has a role for sorption excess of hydrogen proton. The cast composite was irradiated with different doses (10 and $20 \mathrm{KGy}$ ) for compatiblization and blend formation. Characterization of the membranes using FTIR, Thermal gravimetric analysis (TGA), X ray diffraction (XRD) recommend their usage in fuel cell application. Measurements of some impacts such as water uptake and ion exchange capacity and hardness were carried out. Electrical resistivity investigations confirmed the membranes usage into fuel cell. Raising the temperature to $80^{\circ} \mathrm{C}$ resulted in reduction of resistivity to $2.7 \mathrm{ohm}$ which well competes with commercial membranes $\left(\right.$ Nafion $\left.^{\circledR}\right)$.

\section{References}

1. Peach S, Robert D, Polak, Franck C (1996) Characterization of partia monolayers on glass using friction force microscopy. Langmuir 12: 6053-6058.

2. Li Z, Tolan M, Höhr T, Kharas D, Qu S (1998) Polymer thin films on patterned Si surfaces. Macromolecules 31: 1915-1920.

3. Muller BP, Stamm M (1998) Correlated roughness, long-range correlations, and dewetting of thin polymer films. Macromolecules 31: 3686-3692. 
Citation: Abdel-Hady EE, El-Toony MM, Abdel-Hamed MO (2012) Casting Membrane of Acrylamide/Polymethacrylic acid and Reinforced by PAC for Application in Fuel Cell Unit. J Membra Sci Technol 2:111. doi:10.4172/2155-9589.1000111

4. Patton TC (1979) Paint flow and pigment dispersion. In: A Rheological Approach to Coating and Ink Technology. Wiley-Interscience Publication/John Wiley \& sons, USA.

5. Bierwagen GP (1975) Surface dynamics of defect formation in paint films. Prog Org Coat 3: 101-113

6. Hansen CM (1972) Surface dewetting and coatings performance. J Pain Technol 44: 57-60

7. Hayashi M, Ribbe A, Hashimoto T, Weber M, Heckmann W (1998) The influence of wettability on the morphology of blends of polysulfones and polyamides. Polymer 39: 229-308.

8. Machell JS, Greener J, Contestable BA (1990) Optical properties of solvent cast polymer films. Macromolecules 23: 186-194

9. Muller P, O'Neill SA, Affrossman S, Stamm M (1998) Phase separation and dewetting of weakly incompatible polymer blend films. Macromolecules 31 : 5003-5009.

10. Schikk'en K, Claesson PM, Malmsten M (1997) Properties of poly(ethylene oxide)-poly(butylene oxide) diblock copolymers at the interface between hydrophobic surfaces and water, J Phys Chem B 101: 4238-4252.

11. Eskilsson K, Tiberg F (1998) Interfacial behavior of triblock copolymers a hydrophilic surfaces. Macromolecules 31: 5075-5083.

12. Wainright JS, Wang JT, Weng D, Savinell RF, Litt M (1995) Acid-doped polybenzimidazole: a new polymer electrolyte. J Electrochem Soc 142: L121-L123.

13. Savinell RF, Litt MH (1996) US Patent 5,525,436.

14. Wang JT, Savinell RF, Wainright J, Litt $M$, Yu H (1996) $\mathrm{A}_{2} / \mathrm{O}_{2}$ fuel cell using acid doped polybenzimidazole as polymer electrolyte. Electrochim Acta 41: 193-197.

15. Bouchet R, SiebertE (1999) Proton conduction in acid doped polybenzimidazole. Solid State Ionics 118: 287-299.

16. Kawahara M, Morita J, Rikukawa M, Sanui K, Ogata N (2000) Synthesis and proton conductivity of thermally stable polymer electrolyte: poly(benzimidazole) complexes with strong acid molecules. Electrochim Acta 45: 1395-1398.

17. Samms SR, Wasmus S, Savinell RF (1996) Thermal stability of Nafion in simulated fuel cell environment. J Electrochem Soc 143: 1225-1232.

18. Li Q, He R, Jenson JO, Bjerrum NJ (2004) PBI based polymer membrane for high temperature fuel cell-preparation, characterization and fuel cell demonstration. Fuel Cells 4: 147-159.

19. Qingfeng L, Hjuler HA, Bjerrum NJ (2001) Phosphoric acid doped polybenzimidazole membranes: physic chemical characterization and fuel cell applications. J Appl Electrochem 31: 773-779.

20. Liu G, Zhang H, Hu J, Zhai Y, Xu D, et al. (2006) Studies of performance degradation of a high temperature PEMFC based on $\mathrm{H}_{3} \mathrm{PO}_{4}$-doped PBI. J Power Sources 162: 547-552

21. Zhai Y, Zhang H, Liu G, Hu J, Yi B (2007) Degradation study on MEA inH3PO4/ PBI high-temperature PEMFC life test. J Electrochem Soc 154: B72-B76.

22. Wijmans JG, Smolders CA (1986) In Bungay PM, Lonsdale HK, de Pinho MN (Eds.) Synthetic Membranes: Science, Engineering and Application. NATO AS Series, Series C: Mathematical and Physical Sciences.

23. Brandrup J, Immergut EH (Eds) (1989) Polymer Handbook 3rd ed. Wiley, New York, USA.

24. Omata T (2007) J Fuel Cell Technol 7: 6

25. Omata $T$ (2008) Proceedings of the 4th International Hydrogen \& Fuel Cell Expo, FC-2.

26. Shi W, Hou M, Shao Z, Hu J, Hou Z, et al. (2007) A novel proton exchange membrane fuel cell anode for enhancing CO tolerance. J Power Sources 174: 164-169

27. Wan $\mathrm{CH}$, Zhuang QH (2007) Novel layer wise anode structure with improved CO-tolerance capability for PEM fuel cell. Electro Chim Acta 52: 4111-4123.

28. Xing B, Savadogo O (2000) Hydrogen/Oxygen Polymer Electrolyte Membrane Fuel Cells (PEMFCS) Based on Alkaline-Doped Polybenzimidazole (PBI) Electrochem Commun 2: 697-702.
29. Donoso P, GoreckiW, Berthier C (1988) NMR, conductivity and neutron scattering investigation of ionic dynamics in the anhydrous polymer protonic conductor PEO $\left(\mathrm{H}_{3} \mathrm{PO}_{4}\right)_{\times}$. Solid State lonics 28-30: 969-974.

30. Weeks SP, Zupancic JJ, Swedo JR (1988) Proton conducting interpenetrating polymer networks. Solid State lonics 31: 117-125.

31. Vargas MA, Vargas RA, Mellander BE (1999) More studies on the $\mathrm{PVAl}+\mathrm{H}_{3} \mathrm{PO}_{2}+\mathrm{H}_{2} \mathrm{O}$ proton conductor gels. Electrochim Acta 45: 1399-1403.

32. Lassègues JC, Desbat B, Trinquet O, Cruege F, Poinsignon C (1989) From model solid-state protonic conductors to new polymer electrolytes. Solid State Ionics 35: 17-25.

33. Rogriguez D, Jegat C, Trinquet O, Grondin J, Lassègues JC (1993) Proton conduction in poly (acrylamide)-acid blends. Solid State lonics 61: 195-202.

34. Daniel MF, Desbat B, Cruege F, Trinquet O, Lassègues JC (1988) Solid state protonic conductors: Poly (ethylene imine) sulfates and phosphates. Solid State Ionics 28-30: 637-641.

35. Adjemian KT, Dominey R, Krishnan L, Ota H, Majsztrik P, et al. (2006) Function and Characterization of Metal Oxide-Nafion Composite Membranes for Elevated Temperature $\mathrm{H}_{2} / \mathrm{O}_{2}$ PEM Fuel Cells. Chem Mater 18: 2238-2248.

36. Thampan TM, Jalani NH, Choi P, Datta R (2005) Systematic approach to design of higher temperature composite proton-exchange membranes. J Electrochem Soc 152: A316-A325.

37. Kanamura K, Morikawa H, Umegaki T (2003) Observation of interface between Pt electrode and nafion membrane. J Electrochem Soc 150: A193-A198.

38. Eikerling M, Kornyshev AA, Stimming U (1997) Electro physical properties of polymer electrolyte membranes: A random network model. J Phys Chem B 101: 10807-10820.

39. Bia $\mathrm{C}$ Zhanga $\mathrm{H}$, Zhanga $\mathrm{Yu}$, Zhuc $\mathrm{X}$, Maa $\mathrm{Y}$, et al (2008) Fabrication and investigation of $\mathrm{SiO} 2$ supported sulfated zirconia/Nafion ${ }^{\circledR}$ self-humidifying membrane for proton exchange membrane fuel cell applications. Journal of Power Sources 184: 197-203.

40. Zhai Y, Zhang $\mathrm{H}$, Hu J, Yi B (2006) Preparation and characterization of sulfated zirconia $\left(\mathrm{SO}_{4}{ }^{2-} / \mathrm{ZrO}_{2}\right) /$ Nafion composite membranes for PEMFC operation at high temperature/low humidity. J Membr Sci 280: 148-155.

41. Zhang Y, Zhang H, Zhai Y, Zhu X, Bi C (2007) Investigation of self-humidifying membranes based on sulfonated poly (ether ether ketone) hybrid with sulfated zirconia supported Pt catalyst for fuel cell applications. J Power Sources 168 323-329.

42. Zhang Y, Zhang H, Zhu X, Bi C (2007) J Phys Chem B 111: 6391

43. Abdel-Hady EE, Abdel-Hamed MO, El-Toony MM, El-Sharkawy MR (2011) Comparative study between sulfonation and phosphoration for commercial PTFE grafted with Styrene for fuel cell application. J Membra Sci Technol 1: 3.

44. Thampan TM, Jalani NH, Choi P, Datta R (2005) Systematic approach to design of higher temperature composite proton-exchange membranes. J Electrochem Soc 152: A316-A325.

45. Mason EA, Malinauskas AP (1983) Gas transport in porous media: The dusty gas mode. Elsevier, Amsterdam, Netherlands. 